\title{
A CRIANÇA ENQUANTO FRUIDORAS DE ESPETÁCULOS CÊNICOS
}

\section{Resumo}

O objetivo desta pesquisa foi investigar a relação da criança com o espetáculo cênico considerando a atualidade dos produtos artísticos ofertados a esse público. Para desenvolvermos a análise recorremos às contribuições teóricas de Walter Benjamim e Theodor Adorno através da Teoria Crítica, bem como de especialistas da análise do teatro para crianças, que também têm posições mais progressistas sobre o universo infantil.

Palavras-chave: Espetáculo para Crianças- Teoria crítica - Emancipação.

\begin{abstract}
The objective of this research was to investigate a relationship between the child and the scenic spectacle, considering the actuality of the artistic products offered to this public. In order to conceptualize an analysis we turn to the theoretical contributions of Walter Benjamim and Theodor Adorno through Critical Theory as well as theater analysis specialists for children, who also have more opportunities for progress on the infant universe.
\end{abstract}

Keywords: Children's show - Critical theory - Emancipation.

\section{Introdução}

Discutiremos formulações benjaminianas a respeito da criança, e a partir delas buscaremos fomentar também uma discussão sobre a apreciação estética da criança e o teatro para ela produzito. O objetivo é contribuir com as pesquisas sobre o espetáculo infantil considerando aspectos artísticos, estéticos e pedagógicos.

\section{Referencial teórico: Espetáculos Cênicos e Teoria Crítica}

Benjamin, assim como Adorno, faziam a crítica à arte estandardizada, por isso apresentavam uma discussão sobre a perda da aura. Assim, a reprodutibilidade técnica, segundo Benjamin, teria dois impactos: um positivo no sentido de tornar a obra de arte mais acessível e outro negativo, pois extrai da obra de arte a sua aura que não é reproduzida pela técnica. A aura designa, para Benjamim, a singularidade de uma obra de arte original, o "aqui e agora". Porém, a sua tese é de que com a reprodutibilidade técnica da obra de arte essa aura entra em declínio. A arte então se transformou pelo excesso de exposição e produção em série. Com as transformações advindas do avanço das novas tecnologias, houve também uma transformação na percepção estética. Entretanto, a aura está em declínio, não fim, se considerarmos a percepção da obra em 
questão enquanto experiência. Em relação aos espetáculos cênicos, apreciá-lo também é uma experiência estética. Logo, ao estarmos diante de um espetáculo temos a possibilidade de absorvê-lo e percebê-lo de acordo com nossos referências de vida e conhecimentos prévios. Logo, é a partir dessa ressignificação, colocando em movimento a subjetividade que se gera a experiência estética. A experiência se dá na temporalidade do sujeito, ou seja, tem um sentido de interação em Benjamin (1987).

\section{Metodologia}

Através de revisão bibliográfica observamos que tanto Camarotti (2004) como Puppo (1991) fazem as mesmas ressalvas. A autora já apontava desde a década de 70 a falta de um debruçar mais acurado sobre a pesquisa cênica para a atuação com as crianças (considerando que tanto a equipe técnico-artística como os atores sejam adultos). Já Assis (2011) também discute esse objeto, mas seu foco já se direciona para os atores, adultos ou não, que representarão para elas e defende que um espetáculo para crianças é importante não necessariamente porque “ensina” alguma coisa, mas por dialogar com a criança.

Quando o público se identifica com a obra podendo usufruir ao máximo de toda sua polissemia despertará os mais variados sentidos. Assim, mais adepto esse público ficará da comunhão com novos espetáculos sendo formados enquanto fruidores. Assim há a necessidade de se construir um olhar específico para elas sem esteriotipização. É preciso diversificar a cena para que o público não fique viciado a certo "padrão" e assim ter dificuldades de percepção e assimilação de novas propostas cênicas mais emancipadoras.

\section{Considerações finais}

Ao final desse estudo concluímos que é preciso considerar o respeito às fases do desenvolvimento; a possibilidade de completar a obra para que ela se sinta coautora daquele espetáculo e perspectivas de interagir na cena de forma espontânea percebendo o que é essencial no espetáculo, o que de fato é criação, estética e artística. Por isso, falta de metáforas e poesias, de modo que a criança acaba ficando sem espaço para completar a obra com a sua interpretação e imaginação. 


\section{Referências:}

ASSIS, Andre Ferraz Sitonio de. Construção atoral para o teatro infantil: uma proposta de criação cênica. Dissertação de Mestrado. UFMG, 2010.

BENJAMIN, Walter. A obra de arte na era de sua reprodutibilidade técnica. 1987

A criança, o brinquedo e a educação. Tradução: Marcos Vinicius Mazzari. São Paulo: Summus, 1984.

CAMAROTTI, Marco. Dramaturgia no Teatro para Infância e Juventude. In: $8^{\mathrm{a}}$ e $9^{\mathrm{a}}$ Revista do Festival Nacional de Teatro Infantil de Blumenau - Fenatib, 2004. http://www.cbtij.org.br/arquivo aberto/artigos.htm Acesso em 18/12/2017.

PUPPO, Maria Lúcia de Souza Barros. No reino da desigualdade: teatro infantil em São Paulo nos anos setenta. São Paulo: Perspectiva, 1991.

ORTIZ, Fátima. A Linguagem Cênica no Teatro para Crianças. In: $3^{\mathrm{a}}$ Revista do Festival Nacional de Teatro Infantil de Blumenau - Fenatib, 1999. http://www.cbtij.org.br/arquivo aberto/artigos.htm 